\section{Glycoproteins of trabecular meshwork, cornea and sclera}

S.A. CHAPMAN, S. AYAD,

E. O'DONOGHUE, R.E. BONSHEK
S.A. Chapman
R.E. Bonshek

Department of Pathological Sciences

University of Manchester Manchester, UK

S.A. Chapman

R.E. Bonshek

Department of

Ophthalmology

University of Manchester

Manchester Royal Eye

Hospital

Oxford Road

Manchester M13 9WH, UK

Tel: +44 (0)1612765568

Fax: +44 (0)1612736354

e-mail: richard.bonshek

@man.ac.uk

S. Ayad

School of Biological Sciences University of Manchester

Manchester, UK

This work was funded by the Guide Dogs for the Blind Association and Manchester Royal Eye Hospital Research Endowments

\begin{abstract}
Purpose To analyse high-molecular-weight matrix glycoproteins in trabecular meshwork, cornea and sclera using SDS/PAGE and immuno- and lectin blotting.

Method Extracts of normal trabecular meshwork (TM), cornea and sclera were analysed under reducing conditions on SDS/ PAGE. Western blots were stained for total protein, and major high-molecular-weight components were identified by immunoblotting with antibodies to fibronectin (FN) and type VI collagen. Lectin blotting with PSA, MPA and DSA identified some of the glycoprotein glycans.

Results FN antibody bound to the $240 \mathrm{kDa}$ band in TM, cornea and sclera. Type VI collagen antibody bound more strongly to one band and less so to two other bands at $\sim 200 \mathrm{kDa}$ in normal TM and to a ladder of bands in cornea and sclera. PSA and DSA bound at 240, 200 and $140 \mathrm{kDa}$ in TM, cornea and sclera. MPA bound at 240, 200 and 140 kDa in TM and at 240, 200 and $\sim 120 \mathrm{kDA}$ in cornea and sclera.

Conclusions $\mathrm{FN}$ is a component of the band at $240 \mathrm{kDA}$ in TM, cornea and sclera. Normal TM was found to contain relatively more of one of the isoforms of the $\alpha 3$ (VI) chain whilst cornea and sclera contained all the $\alpha 3$ (VI) isoforms. Complex $N$-linked bi/tri-antennary glycans were localised in FN and the $\alpha 1, \alpha 2$ and $\alpha 3$ (VI) chains in TM, cornea and sclera. $O$-linked glycans (identified by MPA binding) were located in FN and $\alpha 3$ (VI) chains of TM, cornea and sclera.
\end{abstract}

Key words Cornea, Extracellular matrix, Sclera, Trabecular meshwork, Type VI collagen

Trabecular meshwork (TM) is the principal regulator of aqueous flow in the human eye, and is considered to operate via complex interrelationships, as yet poorly understood, between extracellular matrix (ECM) and TM cells. The number of cells is known to decrease with age and this decrease occurs to a greater extent in glaucomatous TM. ${ }^{1,2}$ Cell migration and adhesion, together with stabilisation of the ECM, are mediated through specialised and unique domains on ECM molecules. Matrix glycoproteins (GP) of the TM with known binding sites for ECM components and the cell surface include fibronectin $(\mathrm{FN})^{3-6}$ and type $\mathrm{VI}$ collagen. ${ }^{7-10}$ These GP are also found in cornea and sclera - tissues that show very different physical properties and functions whilst sharing many of the same matrix components. ${ }^{11}$

FN binds with high affinity to cell surfaces, collagens and proteoglycans and mediates the attachment of cells to basement membranes and ECM. In the TM it is secreted by TM cells ${ }^{12}$ and has been localised on trabecular beams by immunocytochemical methods. ${ }^{13}$ In cornea, FN has been localised in epithelial basement membrane, stroma and Descemet's membrane. $^{14}$

Type VI collagen is a microfibrillar protein that interacts with cells and $\mathrm{ECM}^{8,9,15,16}$ where it forms extensive networks. ${ }^{17,18}$ Type VI collagen is heterotrimeric, consisting of three genetically distinct $\alpha$ chains, where the molecular mass of each of the $\alpha 1$ and $\alpha 2$ chains is $140 \mathrm{kDa}$, and that of the $\alpha 3$ chains is $\sim 200$ $\mathrm{kDa}$ (using non-collagenous standards). ${ }^{18-20}$ Type VI collagen is believed to play a key role in the maintenance of connective tissue and an age-related increase in a $140 \mathrm{kDa}$ protein in TM extracts has been demonstrated on polyacrylamide gel electrophoresis (PAGE). ${ }^{21}$ Subsequently, immunoblotting identified the $140 \mathrm{kDa}$ protein as $\alpha 1 / \alpha 2$ chains of type VI collagen $[\alpha 1 / \alpha 2(\mathrm{VI})]^{22}$ It has also been identified immunocytochemically in normal $\mathrm{TM}^{23}$ Type VI collagen forms a major constituent of human cornea ${ }^{24}$ and promotes adhesion and spreading of corneal fibroblasts. ${ }^{25}$

The characteristics and function of GP depend on the nature of the glycan component, so that altered glycosylation states can affect cell-matrix and matrix-matrix interactions. The microfibrillar structure of type VI collagen is believed to be due, in part, to the glycosylation of helical domains ${ }^{26}$ where lateral aggregation is restricted, and it is known that the glycans of type. VI collagen and FN include complex $N$ linked and $O$-linked saccharides. ${ }^{26,27}$ In a lectin 
histochemical study of glycan expression in normal $\mathrm{TM}^{28}$ we localised high mannose, complex $N$-linked, bisected and non-bisected bi/tri-antennate glycans on Schlemm's canal endothelium and, to a lesser extent, on trabecular cells and in the cores of trabecular beams. $\mathrm{N}$-acetyl lactosamine and $O$-linked sequences were also identified. When compared with glycan expression in glaucomatous $\mathrm{TM}^{29}$ we observed a decrease in some $N$-linked glycans as shown by binding of PSA (Pisum sativum agglutinin). O-linked glycans, as shown by binding of MPA (Maclura pomifera agglutinin), and $N$-acetyl glucosamine oligomers, as indicated by DSA (Datura stramonium agglutinin), were significantly increased. The associated GP were not identified.

In this preliminary report we have analysed tissue extracts from normal TM, cornea and sclera using PAGE and Western blotting. Blots were stained for total protein and immunoblotted with anti-FN antibody and anti-type VI collagen antibody. Lectin blotting with PSA, MPA and DSA localised some of the glycans present to bands corresponding to the identified GP.

\section{Materials and methods}

\section{Tissue}

Normal TM was obtained from six whole globes, with no ocular pathology. Two of these were taken at autopsy within $12 \mathrm{~h}$ of death (ages 70 and 79 years). Four were obtained from orbital exenteration procedures for sebaceous carcinoma of the eyelid (ages 76, 85 and 68 years) and lacrimal gland carcinoma (age 84 years) where there was no ocular involvement. Cornea and sclera were also acquired from three of these eyes. Normal TM, cornea and sclera from seven time-expired corneas (age range 65-96 years) were obtained from the Eye Bank, Royal Eye Hospital, Manchester.

\section{Preparation of tissue}

Normal TM was excised from the three whole globes by one of two methods. After cutting the eye at the ora serrata and removing the lens, the cornea was positioned resting on the anterior surface and cut radially into segments. The tissue was immediately frozen and stored at $-70{ }^{\circ} \mathrm{C}$. The $\mathrm{TM}$ was readily dissected away from the sclera and cornea by use of a dissecting microscope after thawing, as required. In the second method ${ }^{30}$ the attachments of the ciliary body were severed, and clean partial-thickness cuts were made in front of the scleral spur and behind Schwalbe's line. The TM could then be removed with fine forceps and pulled away, prior to freezing and storage at $-70{ }^{\circ} \mathrm{C}$.

The time-expired corneas included a rim of sclera and TM. After removing the TM with fine forceps, pieces of sclera and cornea (approx. $2 \times 1 \times 1 \mathrm{~mm}$ in size) were cut off and the tissue washed twice with $1 \mathrm{mM}$ phosphate-buffered saline (PBS) $\mathrm{pH} 7.4$ to remove culture medium.

\section{Materials}

Reagents used in the extraction procedures and PAGE, and the lectins PSA and DSA, were obtained from Sigma (Poole, UK). MPA was supplied by Vector Laboratories (UK). Non-collagenous molecular weight standards were obtained from Bio-Rad Laboratories (Hemel Hempstead, Herts., UK). Polyvinylidene fluoride (PVDF) membrane, Immobilon $\mathrm{P}$, was obtained from Millipore (Watford, Herts., UK). Protein binding gold colloid (Protogold), gold-labelled antibiotin $(20 \mathrm{~nm})$ and silver-enhancing kit were obtained from British BioCell International (Cardiff, UK). Two polyclonal antibodies that recognise human type VI collagen were used. One (termed $\mathrm{VIB}^{20}$ ), with principal specificity for the $\alpha 3$ (VI) chain, was raised to bovine type VI collagen but reacts strongly with human type VI collagen. The second (termed VIG, supplied by Gibco BRL), with principal specificity for the $\alpha 1, \alpha 2$ (VI) chains, was solid phase-absorbed with normal human plasma proteins and had no cross-reactivity with human FN. Anti-human FN antibody (monoclonal) was obtained from Gibco BRL (UK) and biotinylated goat anti-rabbit and goat anti-mouse immunoglobulins were obtained from Dako (UK).

\section{Tissue extraction}

The GP were extracted from TM, cornea and sclera by adapting a method described previously. ${ }^{21}$ Briefly, following two washes with PBS $\mathrm{pH} 7.4$, whole TM was extracted into $200 \mu \mathrm{l}$ of buffer containing $0.0625 \mathrm{M}$ Tris$\mathrm{HCl}, 2 \%(\mathrm{w} / \mathrm{v}$ ) sodium dodecyl sulphate (SDS), 10\% (v/ v) glycerol, $8 \mathrm{M}$ urea, $0.1 \mathrm{M}$ dithiothreitol (DTT) and $0.02 \%(\mathrm{w} / \mathrm{v})$ bromophenol blue, and heated at $100{ }^{\circ} \mathrm{C}$ for $5 \mathrm{~min}$. Following centrifugation at $13000 \mathrm{~g}$ for $15 \mathrm{~min}$, the supernatant was removed, the pellet extracted again with the same volume of buffer and the combined supernatants stored at $-20{ }^{\circ} \mathrm{C}$.

The cornea and scleral tissues were cut into pieces measuring approximately $2 \times 1 \times 1 \mathrm{~mm}$ and washed twice with PBS. Each tissue fragment was extracted twice with a volume of sample buffer equivalent to $25 \mu \mathrm{l}$ for each piece of tissue and the tissue extracts were pooled.

Protein concentration was estimated using a comparative dot-blotting technique with known concentrations of prepared standard solutions of bovine serum albumin (BSA). The dot-blotted proteins were visualised using Protogold, a colloidal gold sol that binds quantitatively to proteins blotted onto a membrane. The method used was that recommended by the manufacturers (British Biocell). The colour intensity of the dots was compared visually with that of the standards to give an approximate value of protein concentration.

\section{Gel electrophoresis}

The tissue extracts from individual eyes were each investigated separately and, where possible, extracts of 
$\mathrm{TM}$, cornea and sclera from each eye were analysed on the same gel.

The urea/SDS/DTT-solubilised extracts $(10 \mu \mathrm{l}$ samples, containing approximately equal amounts of protein) were separated by SDS/PAGE on either $6.5 \%$ $(\mathrm{w} / \mathrm{v})$ polyacrylamide gels or ready-prepared $4-20 \%(\mathrm{w} /$ v) gradient gels (BioRad) using the BioRad mini-Protean system (gel size $10 \times 8 \mathrm{~mm}$ ) adapted from the method of Laemmli. ${ }^{31}$ Electrophoresis was carried out in a Tris/ glycine buffer system, pH 8.3 (0.025 M Tris, $0.192 \mathrm{M}$ glycine, $0.1 \%(\mathrm{w} / \mathrm{v}) \mathrm{SDS})$, at a constant voltage of $200 \mathrm{~V}$ at $60 \mathrm{~mA}$ for $40 \mathrm{~min}$. A mixture of biotinylated protein standards was included with each electrophoretic analysis.

The separated proteins were electroblotted onto $0.45 \mu \mathrm{m}$ PVDF membrane using a tank transfer system (Hoefer Mighty Small Transphor unit) with the same transfer buffer as was used in the SDS/PAGE but with $20 \%(\mathrm{v} / \mathrm{v})$ methanol included. Transfer was carried out at $100 \mathrm{~V}$ and $400 \mathrm{~mA}$ for $1.5 \mathrm{~h}$.

\section{Total protein staining}

The blotted membrane was blocked with $0.3 \%(\mathrm{v} / \mathrm{v})$ Tween-20 in PBS for $3 \mathrm{~h}$ at room temperature (RT), washed in distilled water $(2 \times 2 \mathrm{~min})$ and stained with Protogold for 2-4h. Excess Protogold was rinsed off with two $5 \mathrm{~min}$ washes.

\section{Immuno- and lectin blotting}

For immunoblotting, the membrane was blocked with $5 \%$ BSA (w/v) overnight at $4{ }^{\circ} \mathrm{C}$ and incubated with primary antibody for $3 \mathrm{~h}$ at RT. Polyclonal type VI collagen antibodies were diluted 1:1000 and monoclonal

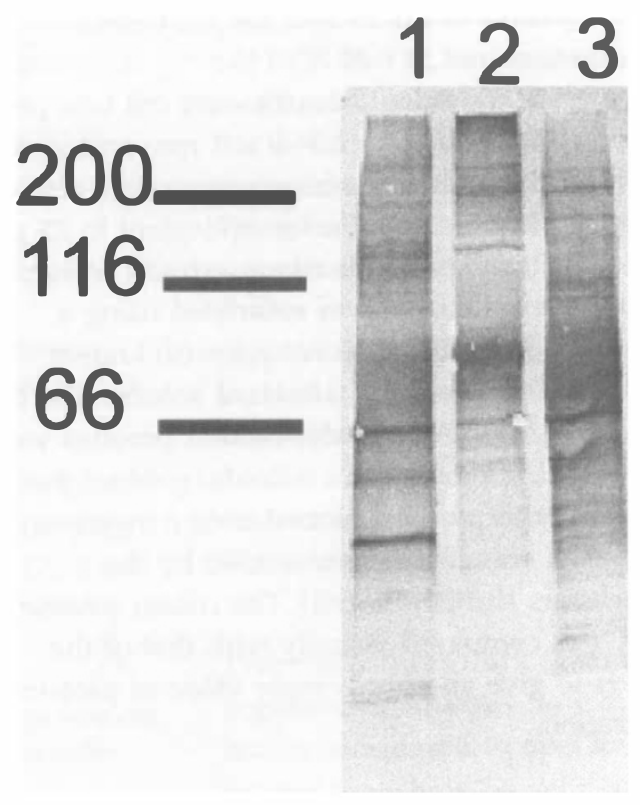

Fig. 1. Analysis of protein in urea/SDS extracts from sclera (lane 1), cornea (lane 2) and trabecular meshwork (TM; lane 3) on Western blots visualised with Protogold (4-20\% gel). High-molecular-weight components at $\sim 240,200$ and $\sim 130 \mathrm{kDa}$ are visible in all three lanes. antibodies 1:500 in PBS containing 1\% BSA (w/v), 1\% (v/ v) normal serum of the species in which the secondary antibody was raised and $0.05 \%$ Tween $20(\mathrm{v} / \mathrm{v})$. After three 10 min washes in PBS containing $0.1 \%(w / v) B S A$, the membrane was incubated for $3 \mathrm{~h}$ at RT with biotinylated secondary goat antibody to rabbit immunoglobulins (following a polyclonal primary antibody) or mouse immunoglobulins (following a monoclonal primary antibody). After three $10 \mathrm{~min}$ washes the membrane was incubated overnight with gold-labelled anti-biotin at RT and finally, after following the same washing procedure, the gold label was silverenhanced. This was done by incubating the membrane in a solution containing equal quantities of initiator and enhancer (Biocell) for 15-20 min, after which the membrane was rinsed for $3 \mathrm{~min}$ with water.

A negative control was included where the primary antibody was replaced with buffer or non-immune serum. BSA and normal serum from the species of the secondary antibody were included to block non-specific binding. A type VI collagen-containing extract from cartilage and a purified FN extract were run simultaneously on one gel to act as positive controls for the type VI collagen and FN antibodies.

For lectin staining, the membrane was blocked overnight in Tris-buffered saline (TBS, $0.05 \mathrm{~m}, \mathrm{pH} 7.6$ ) with $1 \mathrm{mM}$ calcium chloride and $0.05 \%(\mathrm{v} / \mathrm{v})$ Tween 20 . The blotted membranes were incubated with biotinylated lectin (concentration $1 \mu \mathrm{g} / \mathrm{ml}$ ), diluted in the blocking solution, for $2 \mathrm{~h}$ at RT. Following three $10 \mathrm{~min}$ washes in the same buffer, the membrane was incubated with anti-biotin gold diluted 1:100 in the same buffer

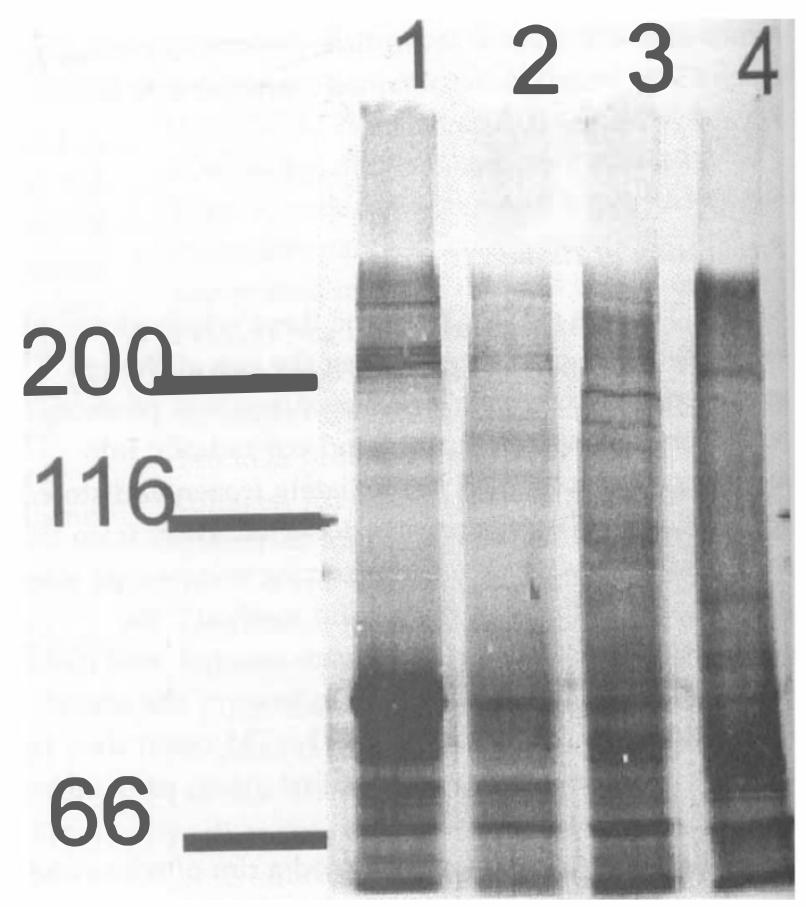

Fig. 2. Analysis of protein in urea/SDS extracts from corme'a (lane 1), sclera (lane 2) and TM (lane 3) from the same eye and TM from a different eye (lane 4) on Western blots visualised with Protogrold $16.5 \%$ gel). In normal TM there is one main component at $\sim 200 \mathrm{kDa}$. In cornea and sclera a ladder of bands is visible at $\sim 200 \mathrm{kDa}$. 
overnight at RT. After three $10 \mathrm{~min}$ washes the gold label was enhanced with silver. For a negative control, the lectin was replaced by TBS. Blots were analysed using the Phoretix 1D Analysis system (Phoretix International, Newcastle, UK).

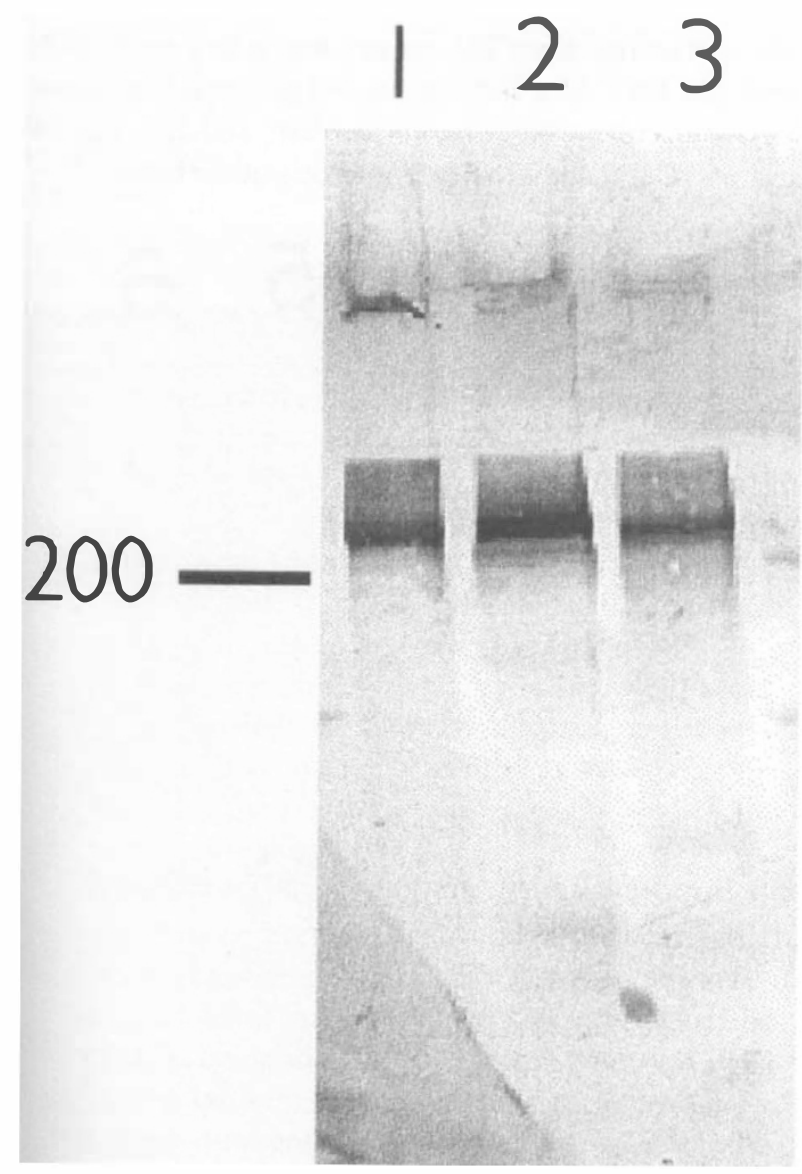

Fig. 3. Identification of fibronectin $(F N)$ in urea/SDS extracts from TM (lane1), cornea (lane 2) and sclera (lane 3) from the same eye. Immunoblot with anti-FN antibody.

\section{Lectin specificity}

The specificity of the lectin binding was confirmed by incubating the lectin with the appropriate inhibiting sugar prior to lectin blotting. PSA (major specificity $\alpha$-D-mannose in non-bisected bi/tri-antennary $N$-linked

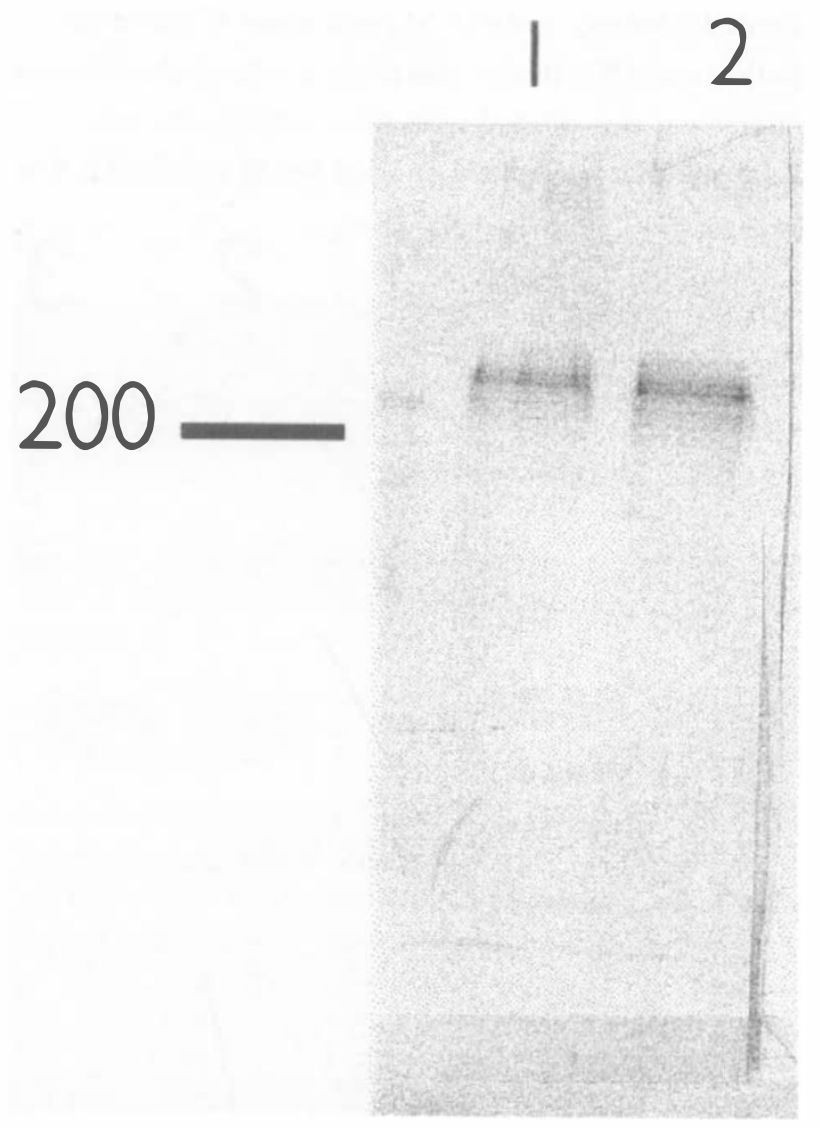

Fig. 4. Identification of FN in urea/SDS extracts from TM (lane 1) and sclera (lane 2). Immunoblot with anti-FN antibody. The band at $240 \mathrm{kDa}$ is visible as a doublet.

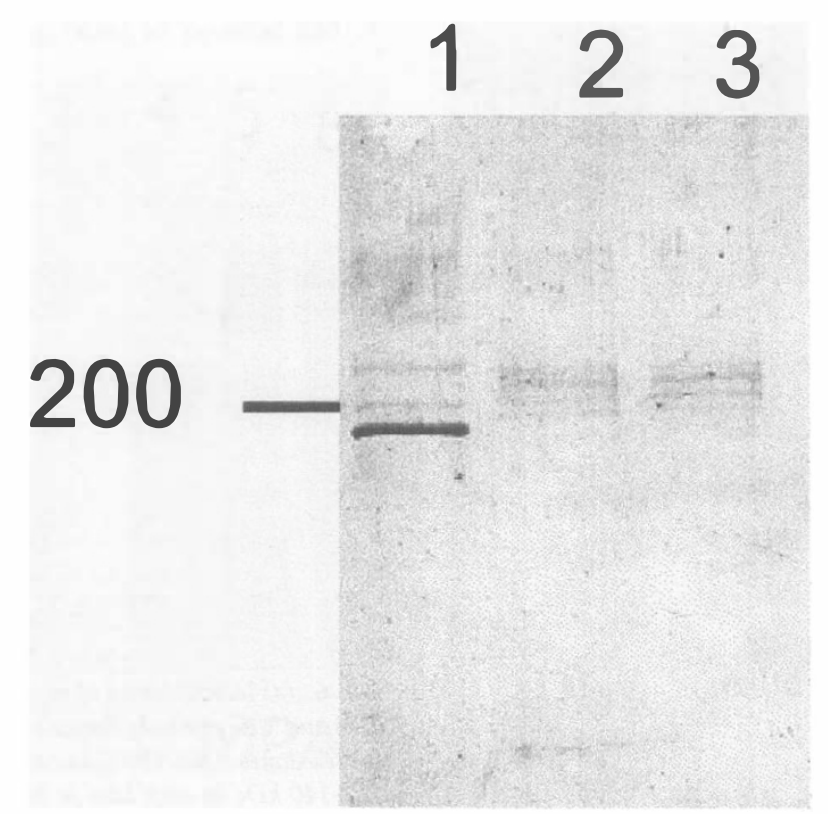

Fig. 5. Identification of type VI collagen with VIB antibody in TM (lane 1), sclera (lane 2) and cornea (lane 3) from the same eye. 
glycans) was diluted to $1 \mu \mathrm{g} / \mathrm{l}$ with $0.5 \mathrm{M} \alpha$-methyl mannopyranoside in $0.05 \mathrm{M}$ TBS with $1 \mathrm{mM}$ calcium chloride and $0.05 \%$ Tween 20 . MPA (major specificity Galß1, 3GalNAc-, where Gal is galactose and GalNAc is $\mathrm{N}$-acetyl galactosamine, on $\mathrm{O}$-linked glycans) was diluted similarly with $0.5 \mathrm{M}$ D-galactose in the same buffer, and DSA (major specificity $\mathrm{N}$-acetyl glucosamine oligomers) was diluted with $\mathrm{D}-\mathrm{N}$-acetylglucosamine. Each solution was mixed and left for $30 \mathrm{~min}$ at RT. The

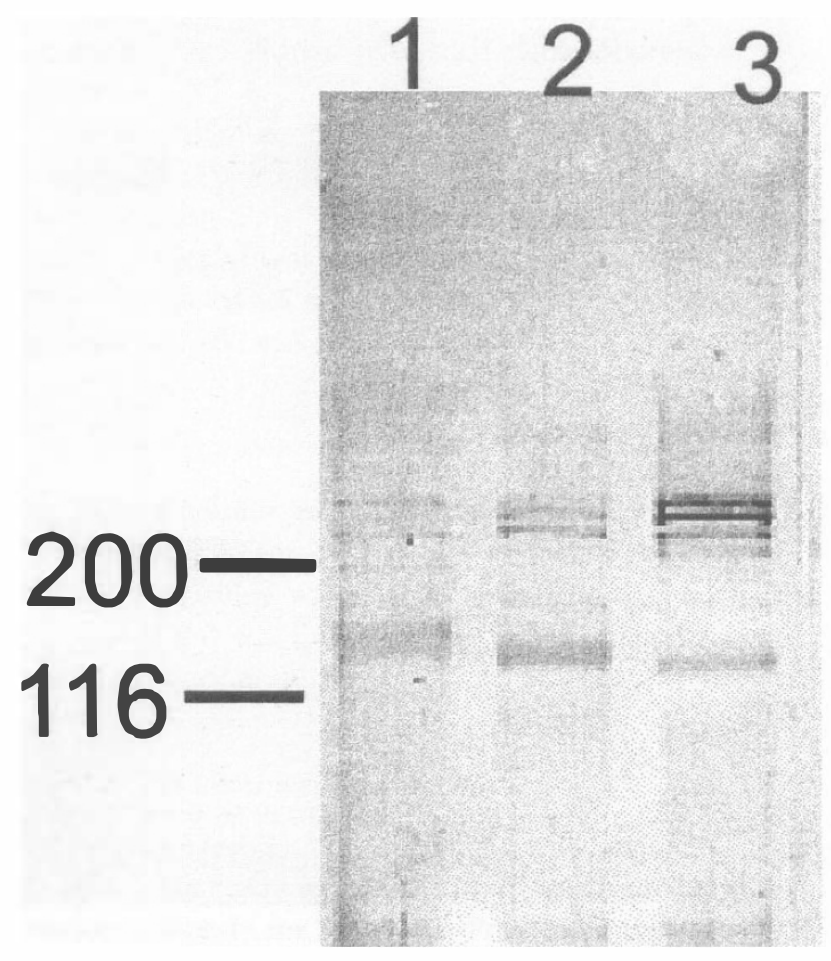

(a)

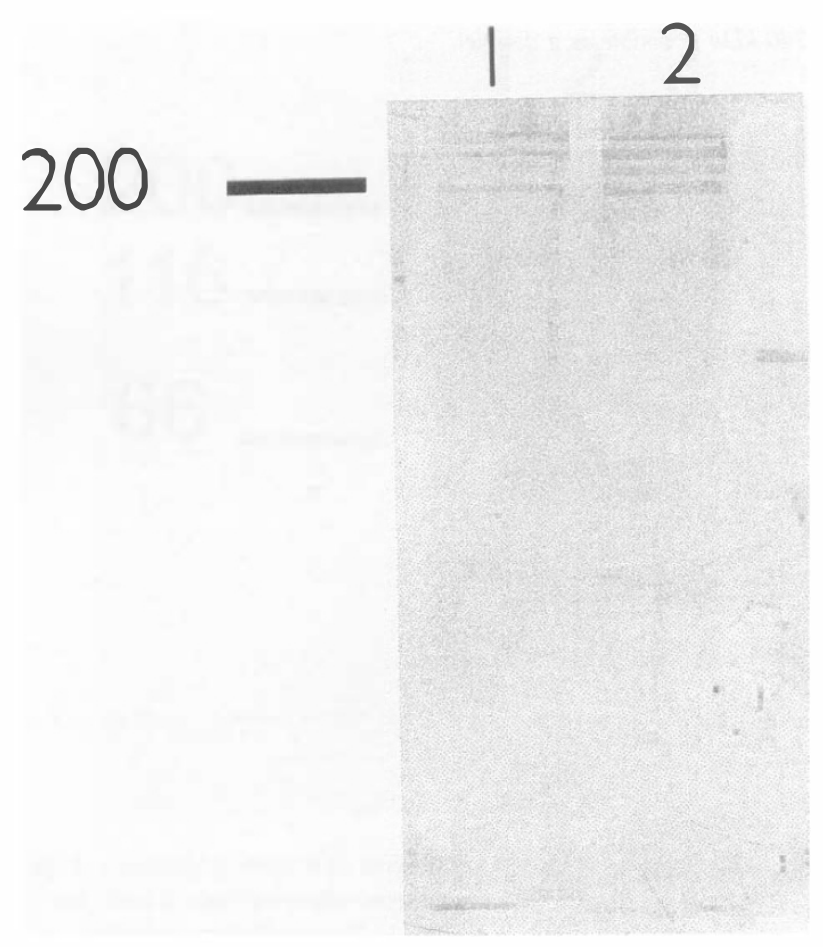

(b) inhibited lectins were each used in a parallel lane and compared with the uninhibited lectin on the same blot.

\section{Results}

\section{Total protein staining}

The extractions from TM, cornea and sclera with SDS/ urea and DTT on 4-20\% graduated gels produced major high-molecular-weight bands at 240, 180-200, 125-130 and $66 \mathrm{kDa}$, together with numerous other faster-

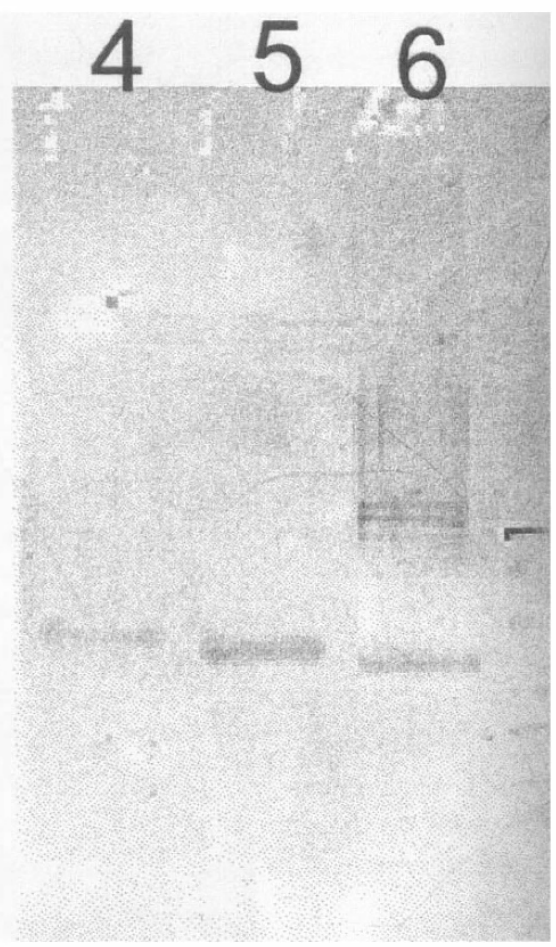

Fig. 6. (a) Identification of type VI collagen with VIB antibody (lanes 1-3) and VIG antibody (lanes 4-6) in TM (lanes 1,4), sclera $(2,5)$ and cornea (lanes 3,6$)$. The tissue extracts are from the same eye. The band at $\sim 140 \mathrm{kDa}$ in each lane is the co-migrating $\alpha 1 / \alpha 2(\mathrm{VI})$ chain. The bands at $\sim 200 \mathrm{kDa}$ in each lane are alternatively spliced forms of the $\alpha 3(V I)$ chain. (b) Type VI collagen-containing extract immunoblotted with VIB antibody. Four bands at $\sim 200 \mathrm{kDa}$ are visible. 


\begin{tabular}{|c|c|c|c|c|c|c|c|c|}
\hline & \multicolumn{8}{|c|}{ Relative molecular mass ${ }^{a}$} \\
\hline & 240 & 200 & 170 & 140 & 120 & 95 & 66 & 45 \\
\hline \multicolumn{9}{|c|}{ Normal TM } \\
\hline PSA & ++ & + & + & + & & + & & + \\
\hline MPA & + & + & & + & + & & & \\
\hline DSA & ++ & + & + & + & & ++ & & + \\
\hline \multicolumn{9}{|l|}{ Cornea } \\
\hline PSA & + & ++ & & + & & & + & \\
\hline MPA & + & + & & & + & & + & \\
\hline DSA & + & + & & + & & & + & \\
\hline \multicolumn{9}{|l|}{ Sclera } \\
\hline PSA & + & ++ & & + & & & + & + \\
\hline MPA & + & ++ & & & + & & + & + \\
\hline DSA & + & + & & + & & & + & + \\
\hline
\end{tabular}

PSA, Pisum sativum agglutinin; MPA, Maclura pomifera agglutinin; DSA, Datura stramonium agglutinin.

${ }^{a}$ Of the principal components observed following electrophoresis.

+ , binding of the lectin to one band at the size indicated; ++ , binding of the lectin to a doublet at the size indicated.

migrating bands. The pattern of major bands produced on analysis of each tissue was the same in individual eyes, with some minor variations in the relative intensities of individual bands. A band at $\sim 100 \mathrm{kDa}$, together with other less distinct bands, was also observed in extractions from normal TM (Fig. 1). When a $6.5 \%$ PAGE gel was used, two bands at 140 and $130 \mathrm{kDa}$ were seen in cornea and sclera (Fig. 2).

Molecular weight estimation of GP on SDS/PAGE is more accurate on gradient gels than on uniform gels; the latter tend to overestimate molecular weight because of the glycan content in the GP. It was assumed that the 125-130 kDa component on 4-20\% gradient gels is the same as the $140 \mathrm{kDa}$ component on a $6.5 \%$ gel.

The main differences observed between the extracts of TM, sclera and cornea were as follows: The single band at $\sim 200 \mathrm{kDa}$ in normal TM was seen as a doublet or as multiple bands in cornea and sclera (Figs. 1, 2). The $140 \mathrm{kDa}$ band in cornea and sclera was relatively stronger than the corresponding band in normal TM. A
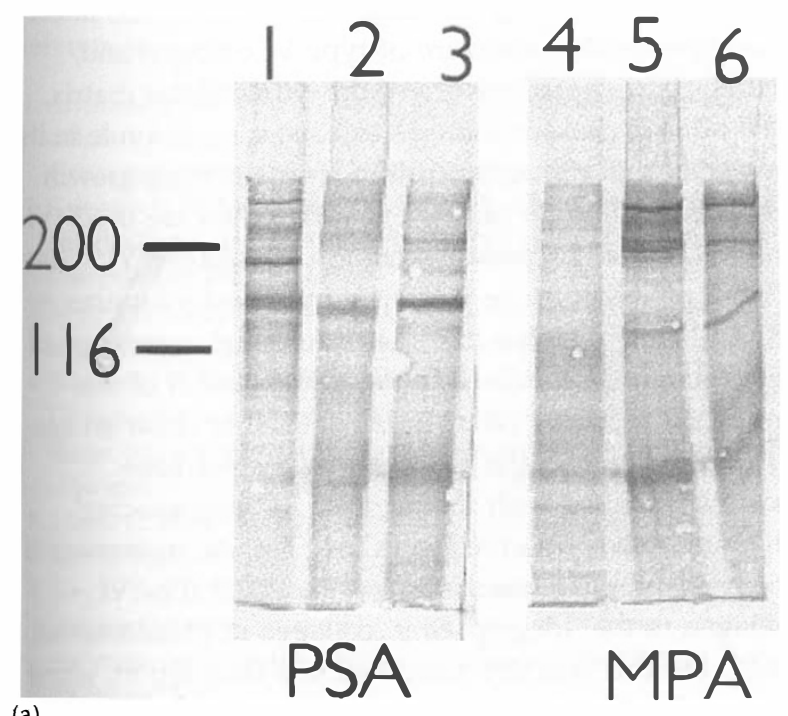

(a)

Fig. 7 (a) Localisation of glycans present in SDS/urea extracts from TM (lanes 1,4), sclera (lanes 2, 5) and cornea (lanes 3, 6) from the same eye with lectins PSA (lanes 1-3) and MPA (lanes 4-6). (b) Localisation of glycans present in TM (lane 1), sclera (lane 2) and cornea (lane 3) with lectin $D S A$. band at $\sim 30 \mathrm{kDa}$ was variable in intensity and was seen prominently in some extracts of sclera, but much less so in others.

\section{Immunoblotting}

Anti-FN antibody bound to the $240 \mathrm{kDa}$ band in normal TM, cornea and sclera (Fig. 3) and was sometimes seen as a doublet (Fig. 4). The control was negative. The antibody bound extensively to the FN standard and degradation products. The VIB collagen antibody, with principal specificity for the $\alpha 3$ (VI) chain, bound to three bands at

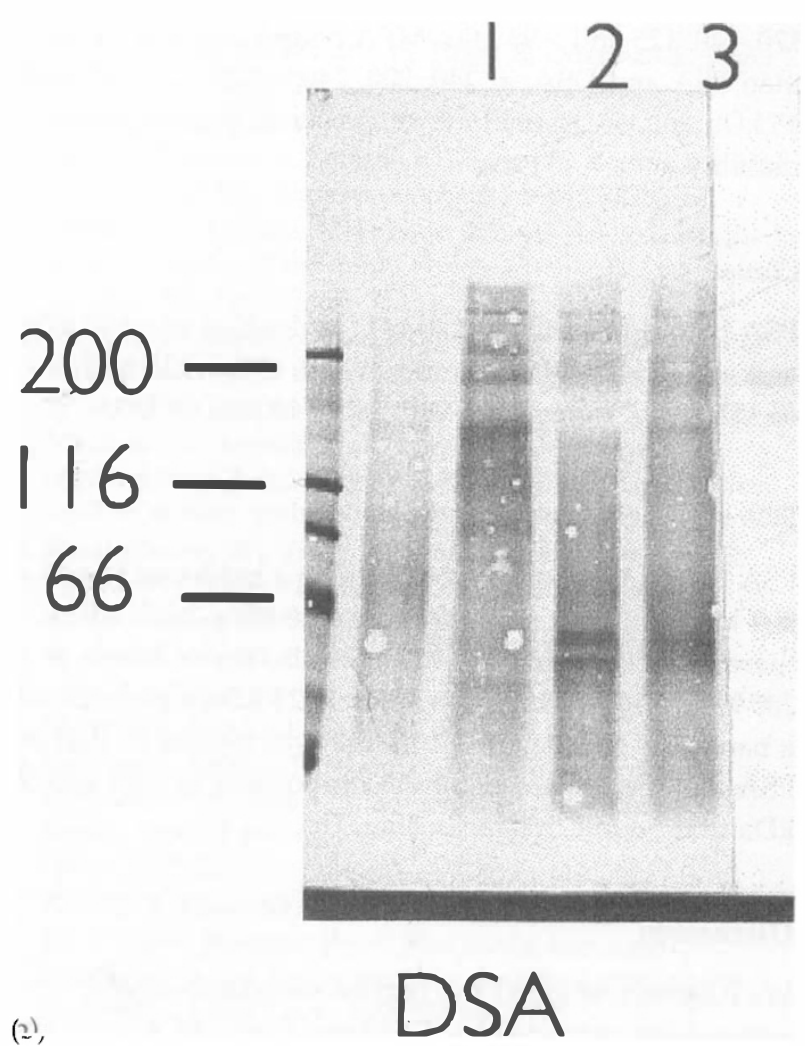


$\sim 200 \mathrm{kDa}$ in normal TM (Figs. 5, 6a). In six of the normal TMs the antibody binding was much stronger to one of the bands compared with the other two (Fig. 5). A prominent band in the same position was observed on blots of normal TM that were stained for total protein. Extracts of cornea and sclera from the same eyes (on the same blot), showed a ladder of four closely spaced bands at $\sim 200 \mathrm{kDa}$ (Figs. 5, 6a). Fig. 6b shows an immunoblot of the type VI collagen-containing extract and the VIB antibody where the four components are visible. Extracts of TM, cornea and sclera from one eye also each showed a band at $\sim 140 \mathrm{kDa}$, with a slightly differing mobility, that was immunoreactive with both type VI collagen antibodies (Fig. 6a). The VIG antibody with specificity for $\alpha 1 \alpha 2$ (VI) bound to the $140 \mathrm{kDa}$ component in TM, cornea and sclera (Fig. 6a).

\section{Lectin blotting}

The binding specificity of the lectins was confirmed by the inhibition experiments, in which the binding of PSA and DSA was totally eliminated and that of MPA was very much reduced. Replacement of the lectin with saline gave a negative result with gold-labelled antibiotin. PSA and MPA binding were in general better defined than that of DSA, which was more diffuse. The results of lectin blotting are summarised in Table 1. An example of lectin blotting of TM, cornea and sclera is shown in Fig. 7.

\section{Normal TM}

PSA and DSA bound most strongly to bands at 240, 200, $170,140,125$ and $\sim 95 \mathrm{kDa}$. MPA bound, but less strongly than PSA and DSA, at 240, 200, 140, $\sim 125,97, \sim 70$ and $45 \mathrm{kDa}$ and occasionally to other bands with a greater mobility.

\section{Cornea}

PSA bound to bands at $240 \mathrm{kDa}$, a doublet at $\sim 190 \mathrm{kDa}$, and at $140 \mathrm{kDa}$. MPA bound at 240,190, $\sim 125$ and $66 \mathrm{kDa}$. DSA bound at $\sim 240,200,140$ and $66 \mathrm{kDa}$.

\section{Sclera}

PSA bound to a band at $240 \mathrm{kDa}$, to a ladder of bands at $200 \mathrm{kDa}$, and to a single band at $140 \mathrm{kDa}$. With MPA, there was binding at $240 \mathrm{kDa}$, to a ladder of bands at $200 \mathrm{kDa}$, and to a component at $\sim 125 \mathrm{kDa}$ together with a band at $\sim 60 \mathrm{kDa}$. DSA binding was similar to that of PSA and there were also two components at $\sim 60$ and 50 $\mathrm{kDa}$ that bound this lectin (Fig. $7 \mathrm{~b}$ ).

\section{Discussion}

We have investigated the higher-molecular-weight components extracted by SDS/ urea from TM, cornea and sclera. The component at $240 \mathrm{kDa}$, which was seen in normal TM, cornea and sclera was identified as FN on the basis of the immunoblotting results with an FN antibody. FN is a dimer of $\sim 250 \mathrm{kDa}$ disulphide-bonded subunits. Each subunit consists of a series of domains having specific functions that include binding to cells, heparin, fibrin and assembly of fibronectin fibrils. ${ }^{32} \mathrm{FN}$ is believed to play an important role in ECM remodelling as well as in cell attachment of trabecular cells to basement membrane of trabecular beams. An increased deposition of FN in TM in primary open angle glaucoma (POAG) has been postulated, although it has not been quantified. ${ }^{33}$ In cornea, FN has been localised in Descemet's membrane and stroma ${ }^{34}$ and has also been implicated in epithelial wound healing.

We have demonstrated by immunoblotting that, in reduced extracts of normal $\mathrm{TM}$, the prominent band at $\sim 200 \mathrm{kDa}$ is the $\alpha 3$ (VI) chain. The ladder of bands in the range $180-240 \mathrm{kDa}$, which is visible in corneal and scleral extracts and binds anti-type VI antibody, is characteristic of the $\alpha 3$ (VI) chain and has been reported in type VI collagen extracts from numerous other tissues. ${ }^{20,35}$ The band at $\sim 140 \mathrm{kDa}$ on $6.5 \%$ gels $(125-130 \mathrm{kDa}$ on $4-20 \%$ gels) observed in extracts of TM, cornea and sclera is identified as the co-migrating $\alpha 1 / \alpha 2$ (VI) chains. Each of the three genetically distinct $\alpha$ chains consists of a short triple helical region with large $\mathrm{N}$ - and C-terminal globular domains. ${ }^{19}$ The globular domains consist of repetitive sub-domains, and alternative splicing can occur in the C-terminal end of the $\alpha 2$ (VI) chain and in at least four subdomains of the N-terminal domain of the $\alpha 3$ (VI) chain. ${ }^{36-38}$

The ladder of bands observed in the type VI collagen standard and corneal and scleral extracts is therefore identified as the alternatively spliced forms of the $\alpha 3$ (VI) chain. It appears that they are produced in different proportions in normal TM, cornea and sclera, with normal TM producing relatively more of one variant, observed as a prominent band at $\sim 200 \mathrm{kDa}$ in blots of TM extractions stained for total protein. Two of the domains include cysteine residues and potential $\mathrm{N}$ glycosylation sites, and hence alternative splicing could affect protein folding and function. ${ }^{39}$ It may also affect the microfibrillar structure of type VI collagen and, thereby, the characteristics of the extracellular matrix. The $\alpha 3$ (VI) chain is thought to have a crucial role in its assembly and tissue deposition. Transforming growth factor beta (TGF- $\beta$ ) causes a selective increase in $\alpha 3$ (VI) mRNA and an increased secretion of collagen VI. ${ }^{40}$ As TGF- $\beta$ is known to be increased in aqueous humour in $\mathrm{POAG}^{41}$ it is possible that the differential expression of $\alpha 3$ (VI) may be involved in the pathogenesis of this condition. Type VI collagen is believed to show an agerelated increase in the TM but this has not been positively linked with the increase in 'long-spacing' $(100 \mathrm{~nm})$ that is observed in POAG TM. An immunogold study at the ultrastructural level localised type VI collagen to the 'long-spacing' collagen in glaucomatous $\mathrm{TM}^{42}$ but this was not confirmed in a later report, where it was identified in the fine network of trabecular cores and the juxtacanalicular network. ${ }^{11}$

Type VI collagen is a major component of cornea ${ }^{24}$ and has been localised immunocytochemically at the 
ultrastructural level in epithelial basement membrane, stroma and Descemet's membrane, though not in the 'long-spacing' collagen. ${ }^{43}$ It is also one of the components of the interfibrillar matrix in sclera. ${ }^{44}$

The binding of PSA, DSA and MPA to FN of TM, cornea and sclera indicates the presence of complex, bi / tri-antennary $\mathrm{N}$-linked glycans and some $\mathrm{O}$-linked glycans. This concurs with reports of known carbohydrates in human FN which, depending on the tissue source, contain bi- or tri-antennary groups. The complex $N$-linked glycans identified on the $\alpha 3$ chains of type VI collagen are linked to asparagine residues in the triple helix where two potential $N$-linked acceptor sites are fully occupied ${ }^{26}$ or to sites in the globular domain. The $O$-linked glycosides of the triple helix of VI collagen are linked to hydroxylysine and not to serine or threonine. ${ }^{26}$ Since MPA binds only to glycans that are $O$ linked via serine or threonine, it is probably binding to sites on the globular domains of the $\alpha 3$ (VI) chain in TM, cornea and sclera. MPA binding to the component at 140 $\mathrm{kDa}$ in normal TM suggests that $\mathrm{O}$-linked glycans are also present in the globular domains of the $\alpha 1 / \alpha 2$ (VI) chains. These glycans are not present (or not available) in cornea and sclera, where MPA binds to a faster component.

\section{Conclusion}

\section{Collagen VI isoforms in TM appear to differ in two} respects from those of cornea and sclera. TM produces relatively more of one variant of the $\alpha 3$ (VI) chain, whereas cornea and sclera express all four variants in apparently similar proportions. There appears to be a greater availability of $O$-linked Gal on the $\alpha 1 / \alpha 2$ (VI) chains of TM than in cornea and sclera. The variation in the expression of type VI collagen isoforms in TM compared with cornea and sclera may be a reflection of the function of type VI collagen in these tissues.

\section{References}

1. Alvarado J, Murphy C, Juster RA. Trabecular meshwork cellularity in primary open-angle glaucoma and nonglaucomatous normals. Ophthalmology 1984;91:564-79.

2. Grierson I, McMenamin PG, Lee WR. The effects of age and antiglaucoma drugs on the meshwork cell population. Res Clin Forums 1982;4:69-92.

3. Spiro RG. Nature of the glycoprotein component of basement membranes. Ann N Y Acad Sci 1978;312:106-13.

4. Bornstein P, Duksin D, Balian G, Davidson JM, Cronch E. Organisation of extracellular proteins on the connective tissue cell surface: relevance to cell-matrix interactions in vitro and in vivo. Ann N Y Acad Sci 1978;312:93-100.

5. Lloyd C. Fibronectin: a function at the junction. Nature 1979;279:473-80.

6. Singer II. The fibronexus: a transmembrane association of fibronectin containing fibres and bundles of $5 \mathrm{~nm}$ microfilaments in the hamster and human fibroblasts. Cell 1979;16:675-72.

7. Aumailley M, Mann K, von der Mark K, Timpl R. Cell attachment properties of collagen type VI and Arg-Gly-Asp dependent binding to its $\alpha 2$ (VI) and $\alpha 3$ (VI) chains. Exp Cell Res 1989;181:463-74.
8. Bonaldo P, Russo V, Bucciotti F, Doliana R, Colombatti A. Structural and functional features of the $\alpha 3$ chain indicate a bridging role for chicken collagen VI in connective tissues. Biochemistry 1990;29:1245-54.

9. Chu M-L, Zhang R-Z, Pan T, Stokes D, Conway D, Kuo H-J, et al. Mosaic structure of globular domains in the human type VI collagen $\alpha 3$ chain: similarity to von Willebrand factor, fibronectin, actin, salivary proteins and aprotinin type protease inhibitors. EMBO J 1990;9:385-93.

10. Timpl R, Chu M. Microfibrillar collagen type VI. In: Yurchenko PD, Birk RP, Mecham RP, editors. Extracellular matrix assembly and structure. New York: Academic Press, 1994:207-42.

11. Marshall GE, Konstas AGP, Lee WR. Immunogold ultrastructural localisation of collagens in the aged human outflow system. Ophthalmology 1991;98:692.

12. Yun AJ, Murphy CG, Polansky JR, Newsome DA, Alvarado JA. Proteins secreted by human trabecular cells. Invest Ophthalmol Vis Sci 1989;30:2012-22.

13. Floyd BB, Cleveland PH, Worthen D. Fibronectin in human trabecular drainage channels. Invest Ophthalmol Vis Sci 1985;26:797-804.

14. Kohno T, Sorgente N, Ishibashi T, Goodnight R, Ryan SJ. Immunofluorescent studies of fibronectin and laminin in the human eye. Invest Ophthalmol Vis Sci 1987;28:506-14.

15. Kielty CM, Whittaker SP, Grant ME, Shuttleworth CA. Type VI collagen microfibrils: evidence for a structural association with hyaluronan. J Cell Biol 1992;118:979-90.

16. Carter WG. Transformation-dependent alterations in glycoproteins of the extracellular matrix of human fibroblasts. J Biol Chem 1982;257:13805-15.

17. Bruns RR, Press E, Engvall R, Timpl R, Gross J. Type VI collagen in extracellular, $100 \mathrm{~nm}$ periodic filaments and fibrils: identification by immunoelectron microscopy. J Cell Biol 1986;103:393-404.

18. Engvall E, Hessle H, Klier G. Molecular assembly, secretion and matrix deposition of type VI collagen. J Cell Biol 1986;102:703-10.

19. Furthmayr H, Wiedemann H, Timpl R, Odermatt E, Engel J. Electron-microscopical approach to a structural model of intima collagen. Biochem J 1983;211:303-11.

20. Ayad S, Marriott A, Morgan K, Grant ME. Bovine cartilage types VI and IX collagens. Biochem J 1989;262:753-61.

21. Millard CB, Tripathi BJ, Tripathi RC. Age-related changes in protein profiles of the normal human trabecular meshwork. Exp Eye Res 1987;45:623-31.

22. Tripathi BJ, Hansen M, Li J, Tripathi RC. Identification of type VI collagen in the trabecular meshwork and expression of its mRNA by trabecular cells. Exp Eye Res 1994;58:181-8.

23. Marshall GE, Konstas GPK, Lee WR. Immunogold ultrastructural localisation of collagens in the aged human outflow system. Ophthalmology 1991;98:692-700.

24. Zimmermann DR, Trueb B, Winterhalter $\mathrm{KH}$, Witmer R, Fischer RW. Type VI collagen is a major component of the human cornea. FEBS Lett 1986;197:55-8.

25. Doane KJ, Yang G, Birk DE. Corneal cell-matrix interactions: type VI collagen promotes adhesion and spreading of corneal fibroblasts. Exp Cell Res 1992;200:490-9.

26. Fujiwara S, Shinkai H, Timpl R. Structure of $N$-linked oligosaccharide chains in the triple-helical domains of human type VI and mouse type VI collagen. Matrix 1991;11:307-12.

27. Zhu BC-R, Fisher SF, Pande H, Calaycay J, Shively JE, Laine RA. Human placental (fetal) fibronectin: increased glycosylation and higher protease resistance than plasma fibronectin. J Biol Chem 1984;259:3962-70.

28. Chapman SA, Bonshek RE, Stoddart RW, Jones CJP, Mackenzie KR, O'Donoghue E, McLeod D. Glycoconjugates of the human trabecular meshwork: a lectin histochemical study. Histochem J 1995;27:869-81. 
29. Chapman SA, Bonshek RE, Stoddart RW, O'Donoghue E, Goodall K, McLeod D. Glycans of the trabecular meshwork in primary open glaucoma. Br J Ophthalmol 1996;80:435-44.

30. Tripathi RC, Tripathi BJ. Human trabecular endothelium, corneal endothelium, keratocytes and scleral fibroblasts in primary culture: a comparative study of growth characteristics, morphology and phagocytic activity by light and scanning microscopy. Exp Eye Res 1982;35:611-24.

31. Laemmli UK. Cleavage of structural proteins during the assembly of the head of bacteriophage T4. Nature 1970;227:680-5.

32. Hynes RO. Fibronectins. New York: Springer-Verlag, 1990.

33. Rodrigues RR, Stephen IK, Foidart J-M, Spaeth GL. Collagen, factor VIII antigen, and immunoglobulins in the human aqueous drainage channels. Ophthalmologv 1980;87:337-45.

34. Tervo T, Sulonen J, Valtonen S, Vannas A, Virtanen I. Distribution of fibronectin in human and rabbit corneas. Exp Eye Res 1986;42:399-406.

35. Colombatti A, Ainger K, Colizzi F. Type VI collagen: high yields of a molecule with multiple forms of $\alpha 3$ chain from avian and human tissues. Matrix 1989;9:177-85.

36. Stokes DG, Saitta B, Timpl R, Chu M-L. Human $\alpha 3$ (VI) collagen gene. Characterisation of exons coding for the amino-terminal globular domain and alternative splicing in normal and tumour cells. J Biol Chem 1991;266:8626-33.

37. Zanussi S, Doliana R, Segat D, Bonaldo P, Colombatti A. The human type VI collagen gene mRNA and protein variants of the $\alpha 3$ chain generated by alternative splicing of an additional 5-end exon. J Bio Chem 1992;287:24082-9.
38. Ayad S, Boot-Handford R, Humphries MJ, Kadler KE, Shuttleworth A, editors. The extracellular matrix facts book. London: Academic Press, 1994.

39. Ball SG, Kielty CM, Shuttleworth CA. Structural implications of alternative splicing in type VI collagen. Biochem Soc Trans 1995;23:514S.

40. Heckmann M, Aumailley M, Chu M-L, Timpl R, Krieg T. Effect of transforming grow th factor- $\beta$ on collagen type VI expression in human dermal fibroblasts. FEBS Lett 1992;310:79-82.

41. Tripathi RC, Li J, Chan WFA, Tripathi BJ. Aqueous humour in glaucomatous eyes contains an increased level of TGF- $\beta 2$. Exp Eve Res 1994;59:723-8.

42. Lütjen-Drecoll E, Rittig M, Rauterberg J, Jander R, Mollenhauer J. Immunomicroscopical study of type VI collagen in the trabecular meshwork of normal and glaucomatous eves. Exp Eye Res 1989;48:139-47.

43. Marshall GE, Konstas AG, Lee WR. Immunogold fine structural localisation of extracellular matrix components in aged human cornea. Graefes Arch Clin Exp Ophthalmol 1991;229:164-71.

44. Marshall GE, Konstas AGP, Lee WR. Collagens in the aged human macular sclera. Curr Eve Res 1993;12:143-53.

45. Marshall GE, Konstas AGP, Lee WR. Collagens in ocular tissues. Br J Ophthalmol 1993;77:515-24. 